\title{
Canada expands networked research-up to a limit
}

The Canadian government has expanded its Networks of Centers of Excellence (NCE), adding around US\$13 million in funding and calling for four new categories of networks, including one for genomics and related research. But because of legislative changes, the funding for the new categories is set to end in 14 years-a stipulation that some find troubling.

Established in 1990 to facilitate the commercialization of new technologies developed from basic research, the NCE funds projects in which scientists from multiple academic and industrial groups collaborate, and the program's annual budget, which in 1997 stood at $\$ 47.4$ million, will be increased by $\$ 90$ million over the next three years. But government changes in the NCE funding rules mean that each category will be evaluated at 7-year intervals, and none can receive government funding for more than 14 years. "The assumption," according to Richard Snell, program officer for the Ottawa NCE, "is that if people are doing the same kind of thing after 14 years, they might not be at the cutting edge."

The call for proposals for genomics technologies specifies that such a network should address genotyping, functional genomics, bioinformatics and the ethical implications of related technologies. Snell did not offer a specific rationale for holding basic genomics research to the same time limit as less-speculative areas of research, such as information and transportation technologies, but suggested that the program's long-term survival could be supported by biotechnology companies that may step in to provide funding after the government pulls out.

Robert Hodges, scientific director of the Protein Engineering NCE (PENCE), says his program is now exploring the idea of having companies pick up the funding shortfall. Funding for the PENCE, established in 1990, is scheduled to end in 2005, and 17 of the 20 projects are now partially supported by corporate partners. Still, Hodges describes the time limit for NCE funding as "something I think the government has to change its mind on," particularly

for evolving fields in biomedical research.

Lap-Chee Tsui, geneticistin-chief at the Hospital for Sick Children in Toronto and a member of the Canadian Genetic Diseases Network, one of the original NCE groups, explains that the NCE program "was intended to create structures that would be self-sustained....and therefore would no longer require federal funding." Unfortunately, the NCEs have so far had only mixed successes in spinning off companies. "Many scientists in the network have not been able to attract venture capital to finance their start-up businesses. That relates to the rather conservative approach of Canadian investors," says Tsui.

Alan Dove, New York

\section{Alternative medicine chief sets research agenda}

Stephen Straus is discovering quickly what a mixed blessing the directorship of the National Center for Complementary and Alternative Medicine (NCCAM) can be. He took up the position last October, only days after Congress approved a substantial hike in the center's budget for the second year running (Nature Med. 6, 7; 2000), but his department is now being pilloried in the press over a $\$ 1.4$ million trial to evaluate a pancreatic cancer regimen consisting of vitamins, a restricted diet and coffee enemas.

A report in The Washington Post pointed to a suspicion that the trial of an alternative medicine regimen, known as the Gonzalez treatment, was funded because of political pressure from congress. But NCCAM supporters defend the study, saying that at least Gonzalez is willing to have his therapy tested with a Phase III trialsomething that many alternative medicine advocates shy away from. The trial was set up based on a controversial prospective study that showed patients on the regimen survived almost three times

longer than the standard for those with advanced pancreatic cancer. Although it was initiated by the National Cancer Institute before Straus' arrival, his center

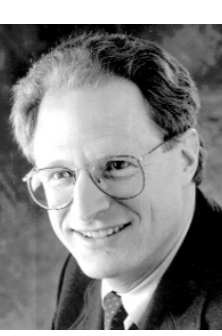
has to foot the bill.

Straus, a 23 year career clinician at the NIH, is acutely aware of the attention focused on his department, and intends to emphasize clinical over basic research, starting with trials of alternative medicines for which there is already some evidence of efficacy in treating medical problems-a trial comparing St. John's wort, Zoloft and placebo for the treatment of mild-to-moderate depression is one example. The market value of St. John's wort was $\$ 6$ billion last year, according to Straus, yet clinical trials have always been too small to definitively answer how effective it is as an antidepressant. He predicts the NCCAM trial will settle the question.

Other NCCAM trials will test whether an extract of ginkgo biloba, a botanical medicine, can prevent dementia in the elderly, and whether glucosamine and condroitin sulfate are useful in treating knee osteoarthritis. "Nobody has done studies that are as definitive as the ones we're doing," he says. "We have just scratched the surface in terms of this kind of clinical trial." He also intends to make his mark by opening NCCAM's doors as wide as possible to clinical investigations of the more than 1,500 botanical medicines used around the world, and is willing to fund foreign investigators who want to test their countries' indigenous medicines in clinical trials.

However, unless Congress steps in a third time, NCCAM will not enjoy the sizable gains in budget that it has in the past two years since the NIH's FY01 estimate for the center is an around $\$ 3$ million compared with $\$ 20$ million for FY00. Tom Hollon, Bethesda

Nature Medicine feedback...

Questions, comments, complaints? We welcome feedback on the news presented here in the print issue of Nature Medicine and in the "Breaking News" feature on our website (http://medicine.nature.com) Please send your comments on the news (or any other aspect of Nature Medicine) to the Senior Editor, News at k.birmingham@nature.com. 